Egyptian Poultry Science Journal

http://www.epsaegypt.com

ISSN: 1110-5623 (Print) - 2090-0570 (On line)

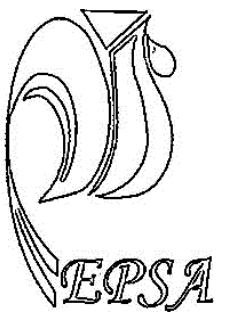

\title{
EFFECT OF FEED SUPPLEMENTED WITH DIFFERENT LEVELS OF SODIUM BENTONITE ON JAPANESE QUAIL PERFORMANCE
}

\author{
Niamat M. El-Abd \\ Environmental Studies \& Rese. Institute, Univ. of Sadat City, Sadat City, Egypt.
}

\begin{abstract}
The effect of feeding different levels of sodium bentonite on Japanese quail chicks performance was studied. An experiment of 42 days was conducted with a flock of 240 unsexed one- day old chicks, distributed at random into 4 groups each in 3 replicates. Treatments were control no additive, T1 containing $2 \%$ sodium bentonite, T2 containing $4 \%$ sodium bentonit and T3 containing $6 \%$ sodium bentonit). All chicks had free access to feed and water ad libitum during the 6-wk experiment. Average daily gain, feed intake and feed conversion efficiency were determined. The results indicated that, chicks fed $4 \%$ and $6 \%$ bentonite had higher body weight gain at 42 days; performance index lower feed intake; and better feed conversion ratio compared to the control diet. Feeding diet containing 6\% had the highest total serum protein, globulin, Glucose and AST concentrations; moreover lower in LDL and HDL than the control diet. No significant effect of different levels of sodium bentonite on the averages values of carcass characteristics. Evidently, it is concluded that the dietary supplementation of Japanese quail chicks with $6 \%$ sodium bentonit resulted in considerable improvement in the growth and economic efficiency without adverse effects on carcass characteristics and constituents of blood serum.
\end{abstract}

Key Words: Sodium bentonite, quail, growth, carcass, blood, economic efficiency.

Corresponding author: niamat.elabd@esri.usc.edu.eg 


\section{INTRODUCTION}

Bentonite as a feed additive has been used successfully in poultry feeds without any harmful effects (Prvulovic et al., 2008; Safaeikatouli et al., 2010). The use of clay supplements in animal and poultry feed manufacturing is not new. Phyllosilicate clays are crystalline, hydrate aluminosilicates that contain alkali and alkaline earth cations, and have a layered structure. Phyllosilicates vary in their composition from one phyllosilicate to another, depending mainly on the interchangeable ions that may be contained within their structure (Phillips, et al., 1994). Bentonite is a clay mineral with strong colloidal properties that absorb water rapidly and results in swelling and increase in volume.

For many years, bentonite has been used as a binder in the feed industry and pharmaceutical preparations (Grosicki, 2008). Aflatoxins severely inhibited the immune system of the birds and reduced the titers of both Newcastle and infectious bursal disease vaccines. Sodium bentonite was able to counteract this effect (Bailey et al., 2006; Kermanshahi et al., 2009 and Shi et al., 2009). Addition of sodium bentonite was significantly effective in ameliorating the negative effect of aflatoxins on the percentage and mean of phagocytosis (Moghadam et al., 2008). Bentonite slowed down feed passage rate for better utilization of feed nutrients (Damiri et al., 2010). Bentonite is tri-layered aluminium silicate having sodium or calcium as its exchangeable cations. Sodium form is the best and mineral hydration results in a fivefold increase in weight. During this change, aluminum silicate layers become separated and water is attracted to their ionic surfaces creating a 12 to 15 fold increase in volume. The ingredients of Bentonite are $\mathrm{SiO} 2$, 66\%; Al2O3, 16.3\%; H2O (Crystal), 60\%; $\mathrm{Fe} 2 \mathrm{O} 3,3.3 \%$; Na2O, 2.6\%; $\mathrm{CaO}, 1.8 \%$; $\mathrm{MgO}, 1.5 \%$; K2O, 0.48\%; $\mathrm{TiO} 2,0.12 \%$
(Salari et al., 2006 and Sallary et al., 2008). Several studies showed that poultry feed supplemented with Bentonite can improve growth performance (Damiri et al., 2010). The special properties of Bentonite such as hydration, swelling, water adsorption and viscosity made it a valuable material for wide range of applications in industrial and farming systems (Miazzo, et al., 2005). Additional studies are necessary to clearly determine the mechanism responsible for the beneficial effects of these zeolites (Safaeikatouli et al., 2010). Little information has been published showing the effects of bentonite on broiler performance and passage rate of diet in gastrointestinal track (Damiri et al., 2011).

The objective of the present study was to determine the impact of different levels of sodium bentonite levels on growth performance, carcass characteristics, some blood parameters and economic efficiency of Japanese quail chicks from 1-42 days of age.

\section{MATERIALS AND METHODS}

The present study was carried out at private Poultry Farm located at Kafr ElShikh, Kafr El-Shikh Governorate, Egypt, in order to investigate the effect of supplementing Japanese quail feed with different levels of sodium bentonite $(\mathrm{NaB})$ treatments on their growth performance, carcass traits, some blood parameters and economic efficiency from 1-42 days of age. Two hundred and forty, unsexed one-day old Japanese quail chicks with an average weight of $\pm 11.2 \mathrm{~g}$ were randomly divided into four dietary treatment groups, (60 birds each). Each group was subdivided into three replicates pens of 20 birds each. Birds were reared in pens with litter (rice straw) from 1 day to 42 days of age under similar managerial and hygienic conditions. Feed and water were provided ad libitum through the whole experimental period. Artificial light was used to provide 24 hours/ day photo period. First group was 
used as a control and fed the starter basal diet; the other three groups (T1, T2 and T3) were fed the same basal diet and supplemented with $2 \%, 4 \%$ and $6 \%$ of sodium bentonite, respectively. The chemical composition of sodium bentonite is presented in Table 2. All diets were formulated to meet the nutrient requirements of the chicks. Feed intake (FI) and body weight (BW) of the birds were recorded at weekly intervals. Body weight gain (BWG), feed conversion (FC) and economic efficiency (EE) were calculated. Performance index (PI) was calculated according to North (1984) as follow:

$\mathrm{PI}=$ live body weight $(\mathrm{kg}) \mathrm{X}$ 100/feed conversion.

At the end of 6 weeks of age, 10 birds were randomly taken from each treatment, fasted overnight, weighed and slaughtered to complete bleeding, followed by plucking the feathers. Dressing, giblets (liver, heart and gizzard) were expressed as relative values to live $\mathrm{BW}$. Blood samples were taken at slaughter time from each bird into tubes, and serum was separated by centrifugation at $3500 \mathrm{rpm}$ for $15 \mathrm{~min}$ and frozen at $-20^{\circ} \mathrm{C}$ for the determination of total protein (TP, g/d), globulin ( $\mathrm{Glb}, \mathrm{g} / \mathrm{d})$, glucose $(\mathrm{Glu}, \mathrm{mg} / \mathrm{dl})$ creatinine $(\mathrm{CR}, \mathrm{m} / \mathrm{d})$, AST, ALT, cholesterol (TC), triglyceride (TG), high density lipoprotein (HDL) and low density lipoprotein (LDL). The proximate analysis of feed was determined according to the methods of A.O.A.C. (2003). The economic efficiency was calculated from the input-output analysis (Heady and Jensen, 1954), assuming that other head costs were constants, as follows: [(price of $\mathrm{kg}$ weight gain-feed cost $/ \mathrm{kg}$ gain)/feed cost $/ \mathrm{kg}$ gain x100] under local conditions. The data obtained were statistically analyzed by the completely randomized design using the general linear models (GLM procedure of statistical analysis system (SAS, 1999. The differences among means were determined using Duncan's Multiple Rang test (Duncan, 1955). Percentages were transformed to the corresponding arcsine values before statistical analysis.

The model applied was:

$Y i j=u+a i+E i j$, where:

$Y i j=$ an observation, $\mathrm{u}=$ overall mean.

$\mathrm{Ai}=$ effect of treatment $(\mathrm{i}=1,2,3,4)$ and

$\mathrm{Eij}=$ experimental random error.

\section{RESULTS AND DISCUSSTION}

\section{Growth performance:}

Body weight gain, Feed intake and feed conversion ratio of Japanese quail fed diets containing different sodium bentonite levels are shown in Table 3 and 4.

Feeding sodium bentonite to chicks had no significant effect on BWG during the whole experimental period. However, those supplemented with 4 and $6 \%$ of $\mathrm{NaB}$ showed slight increase in their BWG than those in control group. At starter phase, diet contained $6 \%$ sodium bentonite had the highest weight gain.

Maximum FI was observed in treatments fed ration containing $\mathrm{NaB}$ at level $2 \%$ and control. While minimum FI was noted at level $6 \%$ and $4 \%$. This is agreement with Damiri et al., (2011), found chickens fed diets contained SB consumed more feed, maximum feed consumption was observed in broilers fed ration containing $0.75 \%$ and $2.25 \% \mathrm{NaB}$ while minimum feed intake was noted in $3.75 \%$ $(p<0.05)$ treatment. The results of Tauqir and Nawaz (2001) showed that 1, 2 and 3\% improved $(\mathrm{P}>0.05)$ weight gain, feed efficiency and final weight; also Pasha etal. (2008) reported these improvements in broilers by 0.5 and $1 \% \mathrm{NaB}$ which confirmed the results of present experiment.

The improvement in weight gain observed in the present study could have been due to the presence of $\mathrm{NaB}$ in the diet, which might have increased feed retention time in the gut of the chicks. Thus subjecting the nutrients to enzymatic action for quite long time, or could have been due to the action of bentonite on the enhanced digestibility of certain nutrients. 


\section{Blood constituents:}

Results of blood constituents as affected by diet supplemented with different levels of sodium bentonite are summarized in Table 5. It is clear that feeding diet containing sodium bentonite at level $6 \%$ and $4 \%$ had the significantly highest Glucose and AST comparing with control. Increasing of AST may due to $\mathrm{NaB}$ raise liver activity. There is no significant difference among treatments in total protein, globulin, creatinine, cholesterol, LDL, HDL and triglyceride. Schell et al. (1993) showed that, feeding sodium bentonite with aflatoxin-contaminated corn (AC) diet results in partial restoration of performance and liver function without greatly influencing mineral metabolism.

\section{Carcass characteristics:}

Carcass characteristics relative to the pre-slaughter weight of quail as affected by dietary supplemented with different levels of sodium bentonite are summarized in Table 6. Results showed that there is no significant effect due to sodium bentonite levels These results are in agreement with those reported by (Damiri et al., 2011) who observed that percentage of sodium bentonite increased, the relative weight of liver decreased $(\mathrm{p}<0.05)$.

\section{Economic efficiency:}

The effect of experimental treatments on the average values of economic efficiency is presented in Table7. According to sodium bentonite levels, the chicks fed diet containing 6\% (T3) recorded the highest values of economic efficiency, followed by chicks which fed diet containing 4\% sodium bentonite (T2), while the lowest value of economic efficiency was obtained by control group.

It is conculuded that addition of sodium bentonite to Japanese quail of diets at level $6 \%$ had benefits effects of growth performance, blood parameters and carcass characteristics, therefore resulted in improved economic efficiency. 
Table (1): Composition and calculated analysis of the experimental diets fed during (1-42) days of age.

\begin{tabular}{|l|l|l|l|l|}
\hline \multirow{2}{*}{\multicolumn{1}{|c|}{ Ingredients }} & \multicolumn{4}{c|}{ Starter diets } \\
\cline { 2 - 5 } & \multicolumn{1}{|c|}{ control } & \multicolumn{1}{c|}{ T1 } & \multicolumn{1}{c|}{ T3 } \\
\hline Yellow corn & 54 & 54 & 53 & 51 \\
Soybean meal (44\%) & 39 & 37 & 37 & 37 \\
bentonite & - & 2 & 4 & 6 \\
Ca carbonate & 0.66 & 0.66 & 0.11 & 0.11 \\
Sodium chloride & 0.35 & 0.35 & 0.10 & 0.10 \\
Vit and mineral premix & 0.50 & 0.50 & 0.50 & 0.50 \\
Di ca phosphate & 1.20 & 1.20 & 1.00 & 1.00 \\
Cotton seed oil & 4.00 & 4.00 & 4.00 & 4.00 \\
Dl-methionine & 0.04 & 0.04 & 0.04 & 0.04 \\
Lysine & 0.25 & 0.25 & 0.25 & 0.25 \\
TOTAL & 100 & 100 & 100 & 100 \\
Calculated analysis ${ }^{2}$ & & & & \\
Crude protein \% & 21.7 & 20.9 & 20.8 & 20.6 \\
ME (kcal/kg) & 2891 & 2847 & 2816 & 2754 \\
C/P ratio & 133 & 136 & 135 & 132 \\
Calcium\% & 0.44 & 0.44 & 0.42 & 0.40 \\
phosphours, \% & 0.30 & 0.31 & 0.28 & 0.26 \\
\hline
\end{tabular}

vitamin and mineral premix. Each $5 \mathrm{~kg}$ of vitamin and minerals mixture contain: Vit $\mathrm{A}$ 1200 I.U., Vit. D3 2000 I.U., Vit E 40 mg, Vit K 34 mg Vit B1 3 mg, Vit B2 6 mg, Vit B6 $4 \mathrm{mg}$, Vit B12 $0.03 \mathrm{mg}$. Niacin $30 \mathrm{mg}$. Pantothenic acid $12 \mathrm{mg}$. Folic acid $1.5 \mathrm{mg}$. Biotin $0.08 \mathrm{mg}$. Choline chloride $700 \mathrm{mg}$. Cu $10 \mathrm{mg}$. I $300 \mathrm{mg}$. Fe $40 \mathrm{mg}$. Mn $80 \mathrm{mg}$. Co $0.025 \mathrm{mg}$., Zn $70 \mathrm{mg}$. and Se. $0.02 \mathrm{mg}$.

${ }^{2}$ Calcaulated according to NRC (1994).

Table (2): The chemical composition of the bentonite

\begin{tabular}{|l|l|}
\hline \multicolumn{1}{|c|}{ Composition } & \multicolumn{1}{c|}{$\%$} \\
\hline $\mathrm{SiO} 2$ & 57.8 \\
$\mathrm{AL} 2 \mathrm{O}$ & 20.8 \\
$\mathrm{Fe} 2 \mathrm{O} 3$ & 3.10 \\
$\mathrm{CaO}$ & 4.20 \\
$\mathrm{MgO}$ & 3.01 \\
$\mathrm{Na} 2 \mathrm{O}$ & 1.10 \\
$\mathrm{~K} 2 \mathrm{O} 57.8$ & 0.05 \\
\hline
\end{tabular}


Table (3): Effect of supplemented sodium bentonite on growth performance at 21 days of age.

\begin{tabular}{|l|l|l|l|l|l|}
\hline \multirow{2}{*}{\multicolumn{1}{|c|}{ Item }} & \multicolumn{3}{c|}{ Dietary treatments } & \multirow{2}{*}{ Sig } \\
\cline { 2 - 5 } & \multicolumn{1}{c|}{ control } & \multicolumn{1}{c|}{ T1 } & \multicolumn{1}{c|}{ T2 } & \multicolumn{1}{c|}{ T3 } \\
\hline Initial body weight,(g) & 11.9 & 12.1 & 12.0 & 11.8 & NS \\
Final body weight,(g) & 125.1 & 123.6 & 127.7 & 129.2 & NS \\
Body weight gain,(g) & 113.2 & 111.5 & 115.7 & 117.4 & NS \\
Feed intake,(g/bird) & $275^{\mathrm{a}}$ & $271^{\mathrm{a}}$ & $265^{\mathrm{b}}$ & $260^{\mathrm{b}}$ & $*$ \\
Feed conversion,(g feed/g gain) & $2.42^{\mathrm{a}}$ & $2.43^{\mathrm{a}}$ & $2.29^{\mathrm{b}}$ & $2.21^{\mathrm{b}}$ & $*$ \\
Performance index $\%$ & 5.16 & 5.08 & 5.57 & 5.84 & NS \\
\hline
\end{tabular}

Means within the same row with different superscripts are significantly different $(\mathrm{P} \leq 0.05)$. Performance index ${ }^{1} \%=($ live body weight, $\mathrm{kg} \mathrm{x} \mathrm{100)/feed} \mathrm{conversion.}$

Table (4): Effect of supplemented sodium bentonite on growth performance at 42 days of age.

\begin{tabular}{|l|l|l|l|l|l|}
\hline \multirow{2}{*}{\multicolumn{1}{|c|}{ Item }} & \multicolumn{3}{c|}{ Dietary treatments } & \multirow{2}{*}{ Sig } \\
\cline { 2 - 5 } & \multicolumn{1}{|c|}{ control } & \multicolumn{1}{|c|}{ T1 } & \multicolumn{1}{c|}{ T3 } & \\
\hline Initial body weight,(g) & 11.9 & 12.1 & 12.0 & 11.8 & NS \\
Final body weight,(g) & 224.5 & 231.5 & 234 & 236.1 & NS \\
Body weight gain,(g) & $212.6^{\mathrm{b}}$ & $219.4^{\mathrm{a}}$ & $222^{\mathrm{a}}$ & $224.3^{\mathrm{a}}$ & $*$ \\
Feed intake,(g/bird) & 905 & 900 & 880 & 870 & $\mathrm{NS}$ \\
Feed conversion,(g feed/g gain) & $4.26^{\mathrm{a}}$ & $4.10^{\mathrm{a}}$ & $3.96^{\mathrm{ab}}$ & $3.87^{\mathrm{b}}$ & $*$ \\
Performance index $\%$ & 5.26 & 5.83 & 5.91 & 6.09 & NS \\
\hline
\end{tabular}

Means within the same row with different superscripts are significantly different $(\mathrm{P} \leq 0.05)$. Performance index ${ }^{1} \%=($ live body weight, $\mathrm{kg}$ x 100)/feed conversion.

Table (5): Effect of supplemented sodium bentonite on some blood serum constituents.

\begin{tabular}{|c|c|c|c|c|c|}
\hline \multirow{2}{*}{ Items } & \multicolumn{4}{|c|}{ Dietary treatments } & \multirow{2}{*}{ Sig } \\
\hline & control & T1 & $\mathbf{T 2}$ & T3 & \\
\hline Total protein $(\mathrm{g} / \mathrm{dl})$ & 4.3 & 4.5 & 3.9 & 4.8 & NS \\
\hline Globulin (g/dl) & 1.81 & 1.72 & 2.00 & 1.95 & NS \\
\hline Creatinine $(\mathrm{mg} / \mathrm{dl})$ & 0.4 & 0.5 & 0.4 & 0.4 & NS \\
\hline Glucose (mg/ dl) & $300^{\mathrm{a}}$ & $320^{\mathrm{a}}$ & $290^{\mathrm{b}}$ & $320^{\mathrm{a}}$ & $*$ \\
\hline $\operatorname{AST}(\mathrm{u} / \mathrm{l})$ & $59^{c}$ & $76^{\mathrm{b}}$ & $89^{\mathrm{a}}$ & $99^{\mathrm{a}}$ & $*$ \\
\hline $\operatorname{ALT}(\mathrm{u} / \mathrm{l})$ & 4 & 4 & 4 & 4 & NS \\
\hline Cholesterol (mg/dl) & 178 & 180 & 200 & 199 & $*$ \\
\hline $\mathrm{LDL}(\mathrm{mg} / \mathrm{dl})$ & 98 & 96 & 97 & 95 & NS \\
\hline HDL(mg/dl) & 55 & 53 & 51 & 49 & NS \\
\hline Triglyceride (mg/dl) & 155 & 151 & 152 & 153 & NS \\
\hline
\end{tabular}

Means within the same row with different superscripts are significantly different $(\mathrm{P} \leq 0.05)$. 
Table (6): Effect of supplemented sodium bentonite on carcass and organ's percentage of Japanese quail

\begin{tabular}{|l|l|l|l|l|l|}
\hline \multirow{2}{*}{ Items } & \multicolumn{3}{c|}{ Dietary treatments } & \multirow{2}{*}{ Sig } \\
\cline { 2 - 5 } & \multicolumn{1}{|c|}{ control } & \multicolumn{1}{|c|}{ T1 } & \multicolumn{1}{|c|}{ T2 } & \multicolumn{1}{|c|}{ T3 } & \\
\hline Pre-slaughter weight (g) & 198.2 & 205 & 195.5 & 200.1 & NS \\
Dressing weight (g) & 178.1 & 180 & 175.4 & 180.5 & NS \\
Dressing (\%) & 89.8 & 87.8 & 88.3 & 89.1 & NS \\
Liver (\%) & 2.8 & 2.5 & 2.5 & 2.7 & NS \\
Heart (\%) & $0.65^{\mathrm{c}}$ & $0.80^{\mathrm{b}}$ & $0.92^{\mathrm{a}}$ & $0.91^{\mathrm{a}}$ & $*$ \\
Gizzard (\%) & 2.79 & 2.75 & 3.06 & 2.98 & NS \\
\hline
\end{tabular}

Means within the same row with different superscripts are significantly different $(\mathrm{P} \leq 0.05)$.

Table (7): The economic efficiency of the experimental diets.

\begin{tabular}{|l|l|l|l|l|}
\hline \multicolumn{1}{|c|}{ Item } & control & \multicolumn{1}{c|}{ T1 } & \multicolumn{1}{c|}{ T2 } & \multicolumn{1}{c|}{ T3 } \\
\hline Price of kg feed (L.E.) & 4.50 & 4.50 & 4.50 & 4.50 \\
Feed conversion,(g feed/g gain) & 4.26 & 4.10 & 3.96 & 3.87 \\
Feed cost of kg weight gain, (L.E.) & 19.17 & 18.49 & 17.89 & 17.53 \\
Market price of 1 kg live weight, L.E.) & 30 & 30 & 30 & 30 \\
Net revenue, (L.E.) & 10.83 & 11.51 & 12.11 & 12.47 \\
Economic efficiency, (\%) & 100 & 106.2 & 111.8 & 115.1 \\
\hline
\end{tabular}

Feed cost of $\mathrm{kg}$ weight gain $=$ Price of $\mathrm{kg}$ feed $\mathrm{x}$ Feed conversion $(\mathrm{g}$ feed/g gain)

Net revenue $=$ revenue from gain - feed cost.

Economic efficiency $=(\text { net revenue } / \text { feed cost })^{*} 100$.

Price of $\mathrm{Kg}$ live body weight was 30 L.E.

Price of one ton bentonite was 200 L.E. 


\section{REFERENCES}

AOAC (2003). Association of Officials Analytical Chemists. Officials Methods of analysis. Vol. 2: 57-58, $16^{\text {th }}$ ed., Washington, DC.

Bailey, C.A.; G.W. Latimer; A.C. Barr; W.L. Wigle; A.U. Haq; J.E. Balthrop and L.F.Kubena (2006). Efficacy of montmorillonite clay (NovaSil PLUS) for protecting fullterm broilers from aflatoxicosis. J. Appl. Poult. Res., 15: 198-206.

Damiri, H.M.; Chaji, M.Bojarpour; M. Eslami and M. Mamoei (2010). The effect of sodium betonites on economic value of broiler chickens diet. J. Anim. Vet. Adv., 9: 26682670.

Damiri, H. M.; Chaji, M.; Bojarpour, M; Eslami and M; Mamoei. (2011). Effect of different level of sodium Bentonite on passage rate of broiler chickens. Proc $3^{\text {rd }}$ Int. Conf. Sustainable Animal Agriculture for Developing Countries (SAADC), Nakhon, Ratchasima, Thailand, 2629 July, 2011, pp: 4017- 4022.

Duncan, D.B. (1955). Multiple range and multiple F tests. Biometrics, 11:142.

Grosicki, A. (2008). Bentonite influence on manganese uptake in rats. Bull. Vet. Inst. Pulawy, 52: 441-444.

Heady, E. O. and H.R. Jensen, (1954). Farm Management Economics. Prentice- Hall Inc. Englewood Cliffs, N.J. USA.

Kermanshahi, H.; A.R. Hazegh and N. A.fzali (2009). Effect of sodium bentonite in broiler chickens fed diets contaminated with aflatoxin B1. J. Anim. Vet. Adv., 8: 16311636.

Miazzo, R.M.; F.Peralta; C. Magnoli; M. Salvano; S. Ferrero; S.M. Chiacchiera; ECQ Carvalho, CAR Rosa and A. Dalcero (2005).
Efficacy of sodium bentonite as a detoxifier of broiler feed contaminated with aflatoxin and fumonisin. Poult. Sci. 84: 1-8.

Moghadam, N. A; A. Sadeghi,; H. Ghahri and P. Shawrang (2008). Effects of yeast cell wall and sodium bentonite on antibody titres of broiler chickens fed ration containing aflatoxin. Proc of British Society of Animal Science (BSAS), Scarborough, UK, 31 March-2 April, 2008, pp: 79-83

NRC. (1994). Nutrient Requirements of Poultry. 9th Ed, Natl Acad Press, Washington, DC.

Pasha, T. N.; A.Mahmood; F.M. Khattak; M.A. Jabbar and A.D. Khan (2008). The effect of feed supplemented with different sodium bentonite treatments on broiler performance. Turk. J. Vet. Anim. Sci. 32: 245-248.

Phillips, T.D.; B.A. Clement and D.L. Park (1994). Approaches to reduction of aflatoxins in foods and feeds. In: The Toxicology of Aflatoxins: Human Health, Veterinary and Agricultural Significance (Eaton, DL and JD Groopman, eds): Academic Press, New York, pp: 383-399.

Prvulovic, D.; D. Kojic, G. GruborLajsic and S. Kosarcic (2008). The effects of dietary inclusion of hydrated aluminosilicate on performance and biochemical parameters of broiler chickens. Turk. J. Vet. Anim. Sci., 32: 183189.

Safaeikatouli M.; F. Boldaji, B. Dastar and S. Hassani. (2010). Effect of different levels of kaolin, bentonite and zeolite on broilers performance. J. Biol. Sci., 10: 58-62.

Salari S.; H. Kermanshahi and H.N. Moghadam (2006). Effect of sodium bentonite and comparison of 
pellet vs. mash on performance of broiler chickens. Int. J. Poult. Sci., 5: 31-34.

Sallary S.; H. Nassirimoghadam and $H$. Kermanshahi, (2008). Effect of sodium bentonite and comparison of pellet versus mash on performance of broiler chickens. Proc British Soc Anim Sci (BSAS), Scarborough, UK, 31 March-2 April, 2008, pp: 273.

SAS (1999). SAS/DSTAT Users Guide. Institute Inc., Cary, NC.

Schell T.C.; Lindemann M.D.; Kornegay E.T.; Blodgett D.J. (1993). Effects of feeding aflatoxin-contaminated diets with and without clay to weanling and growing pigs on performance, liver function, and mineral metabolism.J. Anim. Sci.; 71(5):1209-18.
Shi, Y.; Z. Xu; Y. Sun; C. Wang and J. Feng (2009). Effects of different types of montmorillonite on growth performance and serum profiles of broiler chicks during aflatoxicosis. Turk. J. Anim. Sci., 33: 15-20.

Tauqir, N.A. and H. Nawaz (2001). Performance and economics of broiler chicks fed on rations supplemented with different levels of sodium Bentonite. Int. J. Agri. Biol., 3: 149-150.

Trckova, M.; L. Matlova; L. Dvorska and I. Pavlik (2004). Kaolin, bentonite, and zeolites as feed supplements for animals: health advantages and risks. Vet. MedCzech, 49: 389-399.

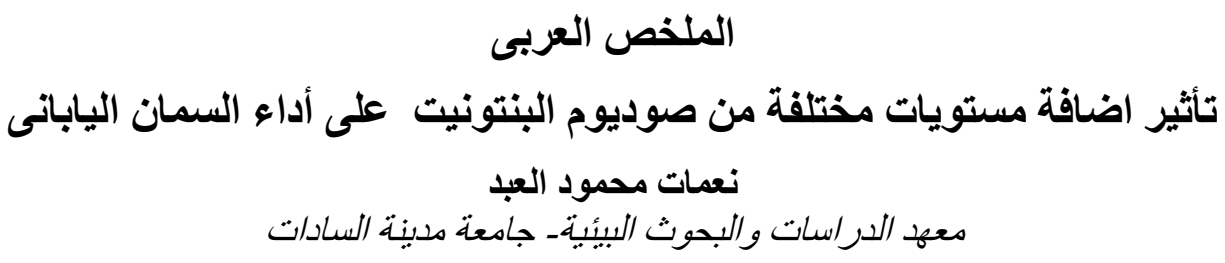

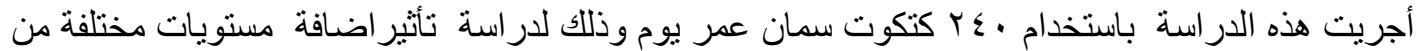

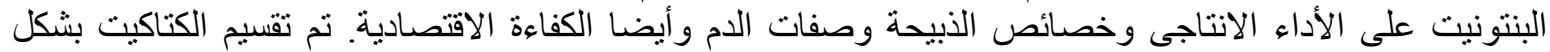

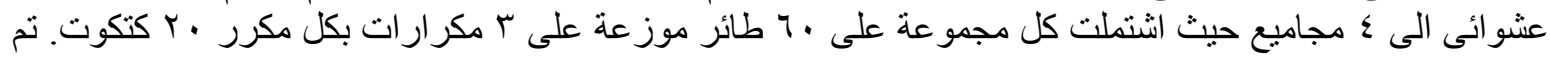

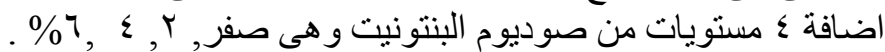

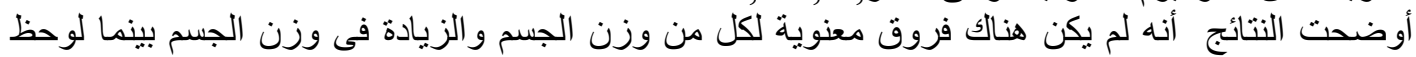

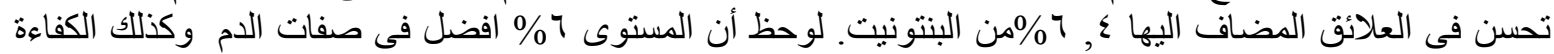

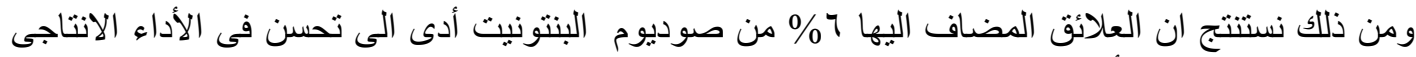
وبالتالى الكفاءة الاقتصادية بدون أثر سلبي على خصائص الذب الذبيحة ومكونات الدم. 